\title{
The difference in saliva pH before and after brushing with fluoride containing toothpaste and without toothpaste
}

\author{
Samuel Setiawan, Edeh Roletta Haroen, Dede Hadidjah \\ Department of Oral Biology Faculty of Dentistry Universitas Padjadjaran
}

\begin{abstract}
In administering fluoride through drinking water there is the risk of overdose, higher cost and inadequate availability of drinking water containing fluoride in developing countries like Indonesia. A safe fluoride source is contained in toothpaste. The purpose of this research was to obtain data concerning difference in saliva $\mathrm{pH}$ before and after brushing with toothpaste containing fluoride and without toothpaste. The research method used was the quasi-experimental method. Samples were collected by the way of purposive sampling, conducted on 43 male and female research subjects. The data were analyzed by statistical analysis using the t test at $95 \%$ confidence level. In this research a control group consisting of 43 people was used. Research results indicated that the average saliva $\mathrm{pH}$ before brushing was 7.174; after brushing with fluoride containing toothpaste salivary $\mathrm{pH}$ was 7.593. Result research of brushing without toothpaste showed an average saliva of 7.163 before brushing and 7.379 after brushing without toothpaste. The average changes in saliva $\mathrm{pH}$ before and after brushing using fluoride containing toothpaste was 0.216 . The conclusion of this research was that there was significant difference in saliva $\mathrm{pH}$ before and after brushing with toothpaste containing fluoride; there was significant difference in saliva $\mathrm{pH}$ before and after brushing without toothpaste, and there was significant difference in saliva $\mathrm{pH}$ before and after brushing with toothpaste containing fluoride and without toothpaste.
\end{abstract}

Key words: Fluoride containing toothpaste, saliva $\mathrm{pH}$

\section{INTRODUCTION}

Recently, fluoride has been used widely to prevent dental caries ${ }^{1}$, its usage is already spread widely in the world starting from the United States to the third world countries. There are several ways of applying fluoride as a caries prophylaxis through the systemic pathway through water, supplement, milk, and salt as well as topical pathway through tooth paste, gel, varnish, and mouth wash. ${ }^{2}$

In all over the world, fluoride application through drinking water is more limited compared to tooth paste use as one of the topical fluoride sources. This may cause by several factors. According Bratthall ${ }^{3}$, fuoridated water is mostly found in modern countries such as United States meanwhile in third world countries, there are small amount of fluoridated water, if any. The use of fluoridated water in a long term creates several disadvantages such as higher dosage and more expensive cost. ${ }^{4}$ A study found that topical fluoride is more effective than systemic fluoride..$^{5,6}$

If used correctly, fluoride is safe and effective in preventing and controlling caries in 
teeth due to fluoride application in small amount periodically everyday will reduce the risk of caries in teeth of almost all age groups. ${ }^{3}$ One of the fluoride sources in Indonesia is toothpaste. By brushing teeth using fluoridated toothpaste, it is expected that a child can absorb fluoride that functions to strengthen the teeth. ${ }^{7}$

By brushing teeth using fluoridated tooth paste can reduce plaque attached on dental surfaces. ${ }^{8}$ The bacterium that plays a role in caries is Streptococcus mutans. ${ }^{9}$ The bacterium produces acid from fermentation process of sugar contains in food that can decrease $\mathrm{pH}$ on dental surface. The acid produced by the bacterium can degrade mineral in enamel such as calcium and phosphor. The process is called demineralization. The decreased $\mathrm{pH}$ will cause faster demineralization dental elements. ${ }^{10}$ The acidic environment in the oral cavity will affect saliva secretion. Saliva secretion can be measured through volume, flow speed, $\mathrm{pH}$ and saliva viscosity.

Saliva secretion has an important role in maintaining dental and oral health through protection function. One of the saliva protection functions is by increasing saliva $\mathrm{pH}$. The saliva $\mathrm{pH}$ will increase after receiving stimulation. The fluoride contained in a toothpaste will affect the saliva composition. The higher the saliva concentration in the mouth, the higher the saliva $\mathrm{pH} .{ }^{10,11}$

\section{MATERIALS AND METHODS}

The type of this research is quasi experimental research. The research materials in the form of saliva were collected using spitting method, i.e. subjects spit saliva from their mouth which was then collected in a beaker glass. The results of the research were analyzed statistically using $t$ test.

The population for this research is students of Dentistry Bachelor Program, Faculty Of Dentistry, Universitas Padjadjaran. The samples were selected using these criteria: male and female, age of 18-25 years old, good general health based on questionnaire data, good dental and oral hygiene, not in antibiotics or other medication therapy, not in radiation therapy, do not wear orthodontic devices or prosthetic devices, non smoker, and have signed informed consent.
The sample size for this research is 43 people who brushed their teeth using fluoridated toothpaste and 43 controls that were taken in a crossover manner who brushed the teeth without using any toothpaste. The sampling technique used in this study is the purposive sampling by taking sample that meets the criteria needed for this study. This study is performed at Student Center Faculty of Dentistry, Universitas Padjadjaran in May and June 2007.

The independent variable in this study is fluoridated toothpaste while the dependent variable is saliva $\mathrm{pH}$. The controlled variable is the same toothbrush type given by the researcher to each subject, duration of tooth brushing of 2 minutes, amount of tooth paste used during the study was maintained at the same level, roll technique of tooth brushing and saliva collection that is performed one hour after meal. This study also consists of uncontrolled variables, i.e. food and beverages consumed one hour before sampling.

The materials and instruments used in this study is tooth brush, beaker glass, paper tissue, stopwatch, pH meter, informed consent, questionnaire, subject's saliva as the tested materials for the study, examination sheet, fluoridated toothpaste, aquadest solution, and buffer 4 and buffer 7 solution for instrument calibration.

The study was started by looking for subjects that meet the necessary criteria in this study. After that, the subjects were asked to fill in questionnaires and sign informed consent.

Next, the subjects were asked to rinse first using aquadest to remove food residuals from the oral cavity and swallow one time to remove residual water from the mouth. The subjects were asked to collect saliva in a standing position, without moving tongue, without swallowing movement and in a close mouth position for 5 minutes. Saliva collected was then spitted into the beaker glass. $\mathrm{pH}$ was then measured using $\mathrm{pH}$ meter and pretooth brushing saliva $\mathrm{pH}$ was noted.

The subjects were then asked to brush their teeth using fluoridated toothpaste for 2 minutes and then rinsed their mouth once. After tooth brushing, the subjects were asked to collect saliva for 5 minutes. The saliva was then spitted and collected in the beaker glass, the $\mathrm{pH}$ is then 
Table 1. Differences saliva $\mathrm{pH}$ before and after brushing $(\mathrm{n}=43)$

\begin{tabular}{lccc}
\hline & Before & After & \multirow{2}{*}{ Note } \\
\cline { 2 - 3 } & Average \pm SD & Average \pm SD & \\
\hline Teeth using fluoridated toothpaste & $7.174 \pm 0.253$ & $7.595 \pm 0.229$ & S \\
Teeth without any toothpaste. & $7.163 \pm 0.291$ & $7.379 \pm 0.287$ & S \\
Differences & $0.421 \pm 0.175$ & $0.216 \pm 0.174$ & S \\
\hline
\end{tabular}

measured using $\mathrm{pH}$ meter and the saliva $\mathrm{pH}$ after brushing teeth with fluoridated tooth paste was noted.

For this study, a control group is needed that consists of 43 subjects taken in a crossover manner. The subjects were instructed to brush their teeth without using toothpaste using the similar steps as the previous procedure.

Data from the study results were analyzed statistically. Table 1 shows the different saliva $\mathrm{pH}$ before and after brushing teeth using fluoridated toothpaste.

Based on the information in Table 1 , it is revealed that the average saliva $\mathrm{pH}$ before treatment is 7.174 with a standard deviation of 0.253 . After brushing the teeth using fluoridated toothpaste, the average saliva $\mathrm{pH}$ increases to 7.595 with a standard deviation of 0.229 . To see the significance of the average difference, a statistical test using paired $\mathrm{t}$-test was performed.

Table 1 also shows the differences in saliva $\mathrm{pH}$ before and after brushing teeth without using toothpaste. Based on the data, it can be seen that the average saliva $\mathrm{pH}$ before treatment is 7.163 with a standard deviation of 0.291 . After brushing teeth without using toothpaste, the average saliva $\mathrm{pH}$ increases into 7.379 with a standard deviation of 0.287 . To see the significance of average differences, a statistical test using paired $t$ test was performed.

Table 1 also shows the differences in saliva $\mathrm{pH}$ changes before and after brushing teeth using fluoridated toothpaste and without toothpaste. It can be discovered that the average saliva $\mathrm{pH}$ change in tooth brushing treatment using fluoridated tooth paste is 0.421 with a standard deviation of 0.175 . The average saliva $\mathrm{pH}$ change in tooth brushing treatment without tooth paste is 0.216 with a standard deviation of 0.174 . To see the significance of the average differences, an independent $t$ test was performed.

\section{DISCUSSION}

Based on the study result data it is found that there is a significant saliva $\mathrm{pH}$ difference before and after brushing teeth using fluoridated toothpaste, a significant saliva $\mathrm{pH}$ difference before and after brushing teeth without toothpaste and a significant saliva $\mathrm{pH}$ difference before and after brushing teeth using fluoridated toothpaste and without toothpaste.

This result is in line with the previous study results in children, i.e. there is a significant saliva $\mathrm{pH}$ increase after brushing teeth using fluoridated toothpaste. ${ }^{12}$ Fluoride concentration in the oral cavity influences the acidity or the saliva $\mathrm{pH}$. The fluoride concentration is linearly comparative with the $\mathrm{pH}$ value of the oral cavity. When the fluoride concentration is low, the $\mathrm{pH}$ will also be low. ${ }^{11}$

The saliva $\mathrm{pH}$ value also depends on the saliva flow speed. The faster the saliva flow is, the more alkaline the saliva $\mathrm{pH}$ that leads to increased saliva $\mathrm{pH}$. On the other hand, the slower the saliva flow is, the more acidic the saliva $\mathrm{pH}^{13}$ The increased saliva flow speed will also make the saliva production increases, meaning that the saliva secretion will also increase. One of the factors that can increase saliva flow speed or saliva secretion speed is the mechanical stimulus..$^{10}$ In this case, the mechanical stimulus is gained from tooth brushing. This finding is also in line with other study's finding that the saliva secretion increases significantly after tooth brushing using fluoridated toothpaste. ${ }^{14}$

For the purpose of this study, the saliva collection was performed one hour after meal to remove the effect of food stimulus. The method used for saliva collection is by spitting method because this method is a simple method and has a quite high accuracy value and is recommended to get saliva in a non stimulated condition. The saliva collection was performed by giving instructions 
first to the subjects to rinse several times using aquadest, perform swallowing movement so that the mouth was in an empty state and collect saliva on the mouth base in a still condition. ${ }^{15}$

Body position will also affect saliva secretion. The saliva secretion in a standing position is higher than in sitting position. ${ }^{16}$ Therefore, in this study, the saliva collection was performed in a standing position so that a maximum saliva secretion was gained. The saliva flows fast during the day, therefore the standard time to measure saliva flow speed is during the day. ${ }^{17}$

\section{CONCLUSION}

Based on these results, some conclusions are taken: There is a significant saliva $\mathrm{pH}$ difference before and after brushing teeth using fluoridated toothpaste; There is a significant saliva $\mathrm{pH}$ difference before and after brushing teeth without using toothpaste; There is a significant saliva $\mathrm{pH}$ difference before and after brushing teeth using fluoridated toothpaste and without toothpaste.

\section{REFERENCES}

1. Cameron AC, Widmer RP. Handbook of pediatric dentistry. $2^{\text {nd }}$ ed. Sydney: Mosby; 2003. p. 2843.

2. Elwood R, Fejerskov O. Clinical use of fluoride. In: Fejerskov O, Kidd EAM. Dental caries the disease and its clinical management. Copenhagen: Blackwell Munksgaard; 2003. p. 189-219.

3. Bratthall. in: Adair $S M$, Bowen WH, Burt BA, Kumar JV, Levy SM, Pendrys DG. Recommendations for using fluoride to prevent and control dental caries in the United States. Morbidity and Mortality Weekly Report (MMWR) 2001 Agustus;17(50):14-52.

4. Dirks OB. Fluorida. In: IImu kedokteran gigi pencegahan. Yogyakarta: Gadjah Mada Universitas Press; 1993. p. 212-74.
5. Craig GC. Fluorides and the prevention of dental decay: A statement from representative board of the British Dental Association. British Dent J 2000;88(12):654.

6. Featherstone JDB. The science and practice of caries prevention. JADA 2000;131:887-9.

7. Fatmasari D, Sunarjo L, Aryati E. Pengaruh metode menggosok gigi terhadap penjerapan fluoride. MIKGI 2003;5(9):231-5.

8. British Nutrition Foundation. Dental health. 2004 [cited 2007 March 20]. Available from: http://www.nutrition.org.uk

9. Helderman WHVP, Veld JHJH, Dirks OB. Plak gigi. In: Ilmu kedokteran gigi pencegahan. Jakarta: C.V. EGC; 1993. p. 1016-17.

10. Amerongen AVN. Ludah dan kelenjar ludah arti bagi kesehatan gigi. Yogyakarta: Gadjah Mada University Press. 1991;6,22,23-40.

11. Ekstrand J, Rolla G. Fluoride in oral fluids and dental plaque. In: Fejerskov O, Ekstrand J, Burt BA, editors. Fluoride in dentistry. $2^{\text {nd }}$ ed. Copenhagen: Munksgaard; 1996. p. 215-21.

12. Wahluyo $S$. Hubungan antara pemakaian pasta gigi berfluorida dengan perubahan $\mathrm{pH}$ saliva berdasarkan interval waktu pada penderita non karies. Research report. JIPTUNAIR. Surabaya: Fakultas Kedokteran Gigi Universitas Airlangga. 2003.

13. Rensburg BGJV. Oral biology. Chicago: Quintessence Publishing Co. Inc.; 1995. p. 459-90.

14. Gedalia I, Brill NE, Raxn F, Friedwald E, Rotmann M, Rosen L. The effect of topical agents on saliva secretion. J Oral Rehabil 1996;23,7,501-4.

15. Navazesh M, Christensen CM. A comparison of whole mouth resting and stimulated salivary measurement procedures. J Dent Res 1982;61(10):1158-62.

16. Peterson D. Family gentle dental care. 2006. [cited 2007 April 12] Avalaible from: http:// www. dentalgentlecare.com.

17. Roth GI, Calmes R. Oral biology. St. Louis: The C.V. Mosby Co.: 1981. p. 196-232. 